\title{
味増川ダム周辺浸透水の長期水質調査による 基礎岩盤の透水性評価手法の提案 \\ PROPOSAL OF ESTIMATION METHOD OF ROCK MASS PERMEABILITY \\ BASED ON LONG TERM WATER QUALIRY INVESTIGATION OF SEEPAGE WATER AROUND MISOGAWA DAM
}

\author{
今井久 1 - 山下亮 1 - 塩崎功 2 - 竹内祐治 3 - 小澤広幸 $4 \cdot$ 関谷松男 5 \\ Hisashi IMAI, Ryo YAMASHITA, Isao SHIOZAKI \\ Yuji TAKEUCHI, Hiroyuki OZAWA and Matsuo SEKIYA
}

\author{
1正会員 工修 ハザマ技術・環境本部技術研究部 主任研究員（テ305-0822 茨城県つくば市荻間515-1） \\ 2正会員 工博 ハザマ技術・環境本部原子力部＼cjkstart課長（†107-8658 東京都港区北青山2-5-8） \\ 3 水資源開発公団味噌川ダム管理所 管理課 \\ （干399-6203 長野県木曾郡木祖村大字小木曽2058-22）

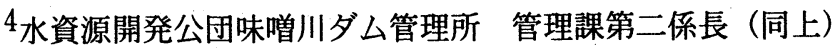

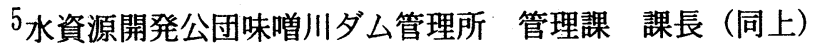

\begin{abstract}
The water quality investigation of seepage water around Misogawa dam has been conducted for more than six years since the start of the initial filling of the reservoir. The investigated data show the water quality was affected by the intrusion of reservoir water to the rock mass around the dam. The electric conductivity (EC) which represent the water quality gradually evolved according to the filling of the reservoir. The evolution of EC was modeled considering the advection and water-rock reaction. The hydraulic conductivity was estimated by curve matching relevant to the measured EC using the EC model simulation. The simulated results and the measured data show good agreement and the estimated hydraulic conductivity was acceptable value. The result of applying the EC model to this site presents the availability of the model and the efficiency for estimating the hydraulic conductivity.
\end{abstract}

Key Words : rockfill dam, seepage water, water quality, hydraulic conductivity finite difference method

1. はじめに

味噌川ダム 1)，3) は1993年12月に湛水を開始した. 湛 水開始以来現在まで約 6 年間にわたり堤体の安定性評価 のため堤体および堤体基礎岩盤内浸透水の水質調査を継 続している.

この調査結果から, 浸透水の水質は他のダムでの調査 2),4）と比較し, 非常に溶存イオンが多く, 湛水に伴う 緩やかな変化特性を持つことが明らかとなった。

貯水池水の到達と考えられる明らかな水質変化が認め られる場合, 湛水開始から水質変化時点までの時間とお よその浸透距離からダム基礎岩盤の透水係数が推定でき
る. しかし, この調査では, 水質の変化が緩やかで, 貯 水池水の到達と考えられる明らかな水質変化が認められ なかった. このため, 浸透水の水質の一指標である電気 伝導度に着目し，貯水池水の基礎岩盤への浸透に伴う電 気伝導度変化のモデル化を試みた. このモデルの 1 パラ メ一夕として堤体基礎岩盤上下流方向の平均的透水係数 を設定し, 電気伝導度の実測值とモデル計算值をカーブ マッチングすることにより堤体基礎岩盤上下流方向の平 均的透水係数を推定した.

本研究は, 調查事例の少ない初期湛水からの長期にわ たる水質の経時変化デ一夕を示すとともに, 浸透水の電 気伝導度変化から堤体基礎岩盤の透水性を評価する方法 を提案し，その適用例を示すものである. 


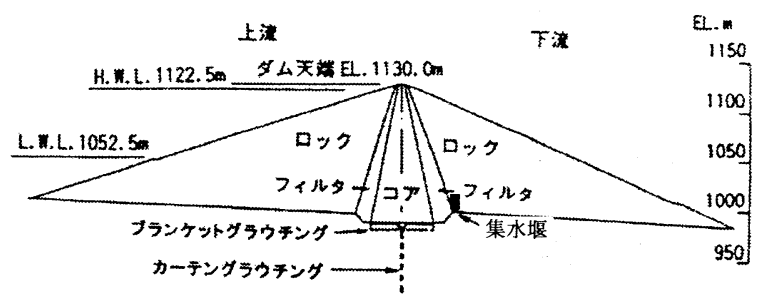

(a) ダム標準断面図

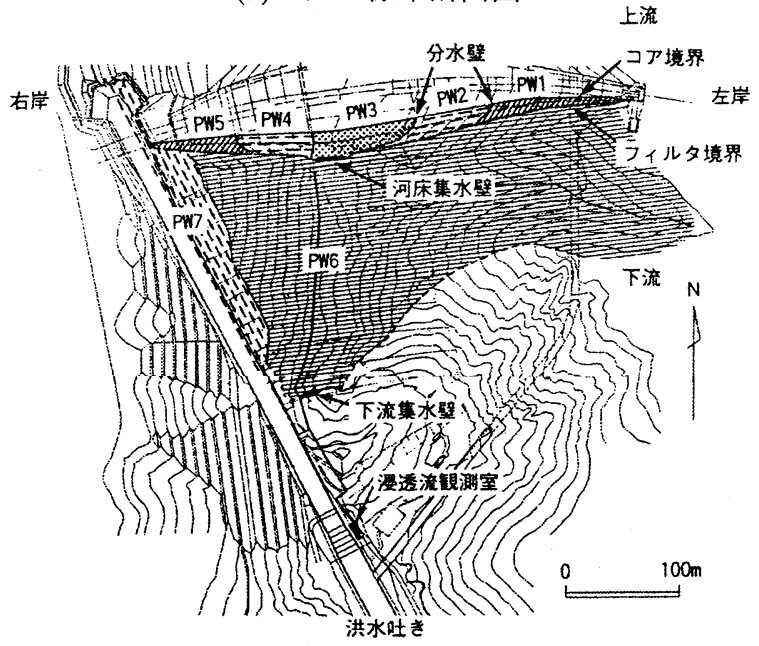

(b) 浸透量観測施設平面図

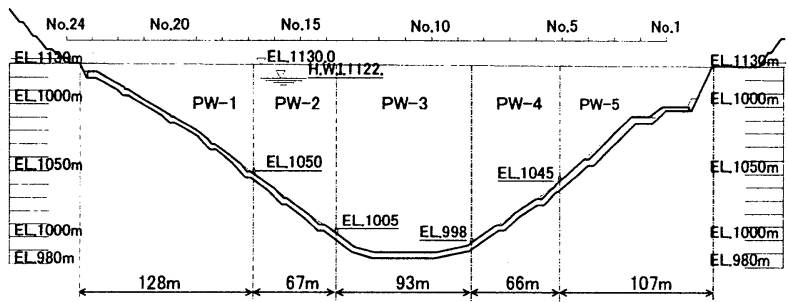

(c) ダム軸断面における浸透量観測の区分

図－1 ダムと観測施設の構造・位置関係図

\section{2. 調査概要}

\section{（1）調查場所}

味噌川ダムは堤高 $140.0 \mathrm{~m}$ ，堤頂長 $446.9 \mathrm{~m}$ ，貯水容量 $61,000,000 \mathrm{~m}^{3}$ の大規模な中央遮水型ロックフィルダム で，その標準断面，平面図を図－1 (a) (b)に示す.

ダムサイトの地質は砂岩, 粘板岩およびそれらの互層 からなっている. 基礎処理はカーテングラウチング改良 目標值 3 ルジオン, ブランケット改良目標值 10 ルジオ ンで施工（セメント系グラウトミルク使用）されている. 水質調查は貯水池表面水と 7 力所の浸透水集水域水 (PW1, PW2, PW3, PW4, PW5, PW6, PW7) で 浸透水集水域の位置・ 区分図を図 - 1 (b), (c)に示す.

PW1〜PW5浸透水は堤体下流フィルータゾーン部の 浸透水を集めたものである. PW6は堤体下流浸透水, PW7は堤体下流の右岸からの浸透水を対象としている.

集水は各集水域下流部に設けられた集水堰でせき止め られ集水管を通じ浸透量観測室へ導かれている，水質調 査は浸透量観測室の水を採取して実施した。
表 - 1 各調査項目の分析方法

\begin{tabular}{|c|c|c|}
\hline 分析項目 & 単位 & 分析方㳎・機器 \\
\hline $\mathrm{pH}$ & & ガラス電極法 \\
\hline 電気伝導度 & $\mu \mathrm{S} / \mathrm{cm}$ & 電気伝導度計 \\
\hline $\begin{array}{l}\mathrm{Na}^{+}, \mathrm{K}^{+}, \mathrm{Ca}^{2+}, \mathrm{Mg}^{2+}, \mathrm{Cl}^{-}, \\
\mathrm{SO}_{4}{ }^{2-}, \mathrm{N0}_{3}{ }^{-}\end{array}$ & $\mathrm{mg} / \mathrm{l}$ & $\begin{array}{l}\text { イインクロマトグラフ法 } \\
\text { DIONEX 2020i-3 }\end{array}$ \\
\hline $\mathrm{HCO}_{3}^{-}$ & $\mathrm{mg} / \mathrm{l}$ & 上水試験法 \\
\hline $\mathrm{SiO}_{2}$ & $\mathrm{mg} / \mathrm{l}$ & 吸光光度法 \\
\hline ラドン ${ }^{222} \mathrm{Rn}$ & $\mathrm{Bq}$ & $\begin{array}{l}\text { 低バックグラウンド液体シン } \\
\text { チレーションカウンシ } \\
\text { (LSC-LB I ) }\end{array}$ \\
\hline
\end{tabular}

\section{（2）調查項目}

調査項目は水質の代表的な指標である $\mathrm{p} \mathrm{H}$ ・電気伝導 度・水温と, 地下水の主要溶存成分であるイオン濃度 $\left(\mathrm{N} \mathrm{a}^{+}, \mathrm{K}^{+}, \mathrm{Ca}^{2+}, \mathrm{Mg}^{2+}, \mathrm{Cl}^{-}, \mathrm{S} \mathrm{O}_{4}{ }^{2-}, \mathrm{N}\right.$ $\mathrm{O}_{3}{ }^{-}, \mathrm{HCO}_{3}{ }^{-}$, $\mathrm{S} \mathrm{i} \mathrm{O}{ }_{2}$ ), さらに放射性同位体であ るラドン ${ }^{22} \mathrm{Rn}$ を対象とした.

$\mathrm{pH}$ ・電気伝導度・水温は採水時に現地にて計測する とともに, 試験室にてイオン濃度を分析する際に再度計 測した. イオン濃度とラドン濃度の分析は, 採水後速や かに試験室に持ち帰り分析を行った. 各調査項目の分析 方法を表 - 1 に示す.

\section{3. 計測データ}

通常実施されるダム管理上の計測データとして日降雨 量, 貯水位, 浸透水PW1からPW7の流量の経時変化, 水質調査データとして浸透水PW1からPW7 と貯水池水 の電気伝導度・カルシウムイオン・硫酸イオン濃度の経 時変化を図 - 2に示す. 浸透水PW1からPW7 と貯水池 水の溶存イオン濃度の経時変化をへキサダイヤグラムと して図 - 3 に示す. 浸透水PW1からPW7のラドン濃度 は7〜15 B q程度であった. 浸透水PW1からPW7と 貯水池水の $\mathrm{pH}$ H $6 \sim 8$ 程度であった. また, 貯水池の 水深約 $100 \mathrm{~m}$ の試料は約 $60 \mu \mathrm{S} / \mathrm{cm}$ であった.

計測データの特徴として以下のことが挙げられる.

(1)浸透量は貯水位と降雨量の影響を受け変化する.

(2)溶存イオン濃度（カルシウムイオン・硫酸イオン） と電気伝導度はよく類似した变化傾向を示す。

(3)PW1からPW6は溶存イオンが多く, 類似した水質 組成を示し, 浸透過程で溶存イオンを取り込んだと 考えられる. また経時変化をみると溶存物質構成比 はあまり変化せず全体の濃度が小さくなる傾向がみ られ，一様に希釈されてきていると考えられる.

(4)浸透水PW1からPW6の全体的傾向は, 明らかに貯 水池水か椡達したと考えられる顕著な変化は示さず, 湛水初期に溶存イオンや電気伝導度は一時低下傾向 を示すがその後湛水開始より 1 年半までは増加し, その後徐々に低下し，5年目くらいからほぼ一定と なっている. これは湛水に伴い地下水の押し出しに 

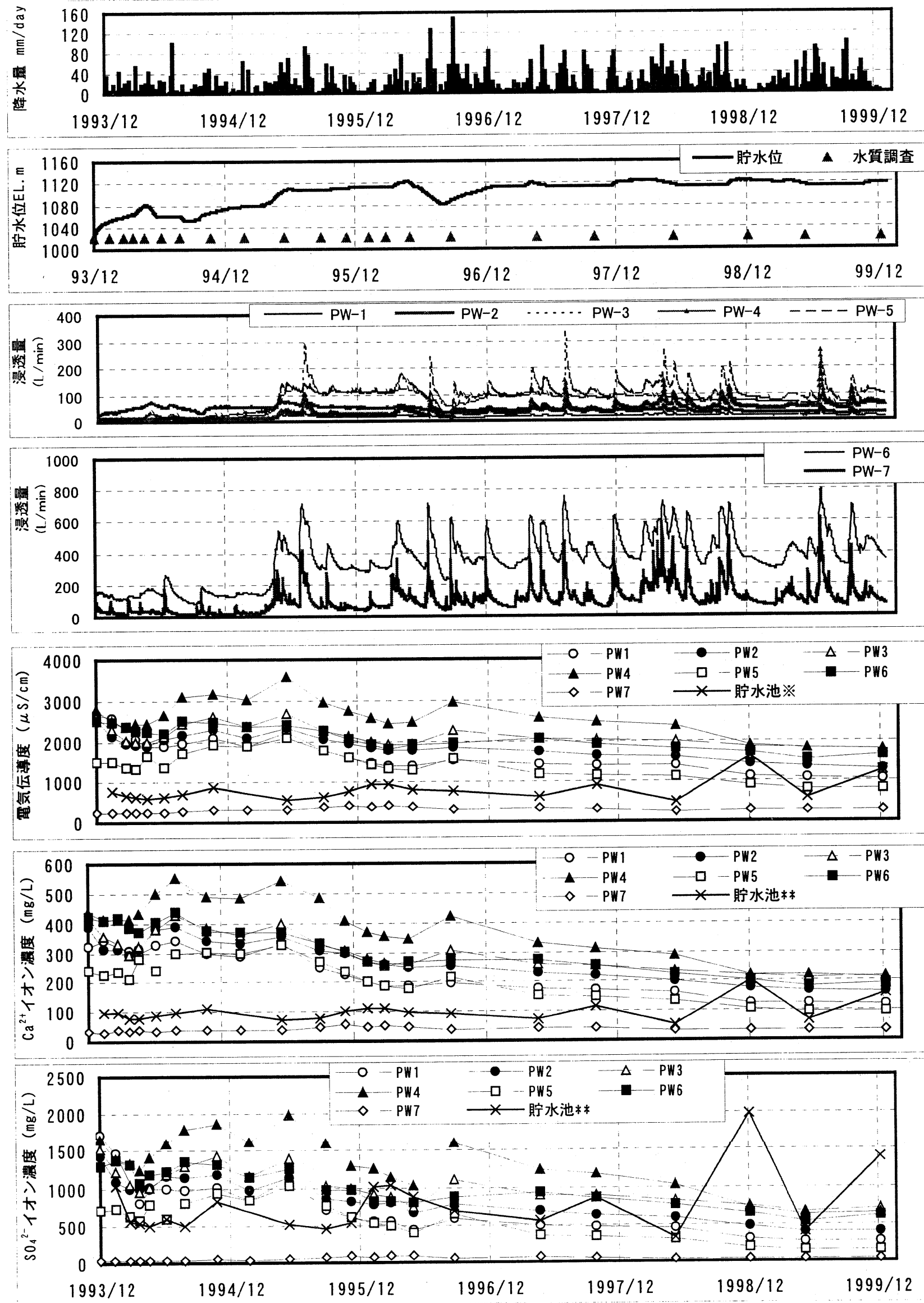

図 - 2 各計測項目の経時変化

（※貯水池の電気伝導度は 10 倍， $* *$ 貯水池のイオン濃度は 100 倍して表示している. ） 


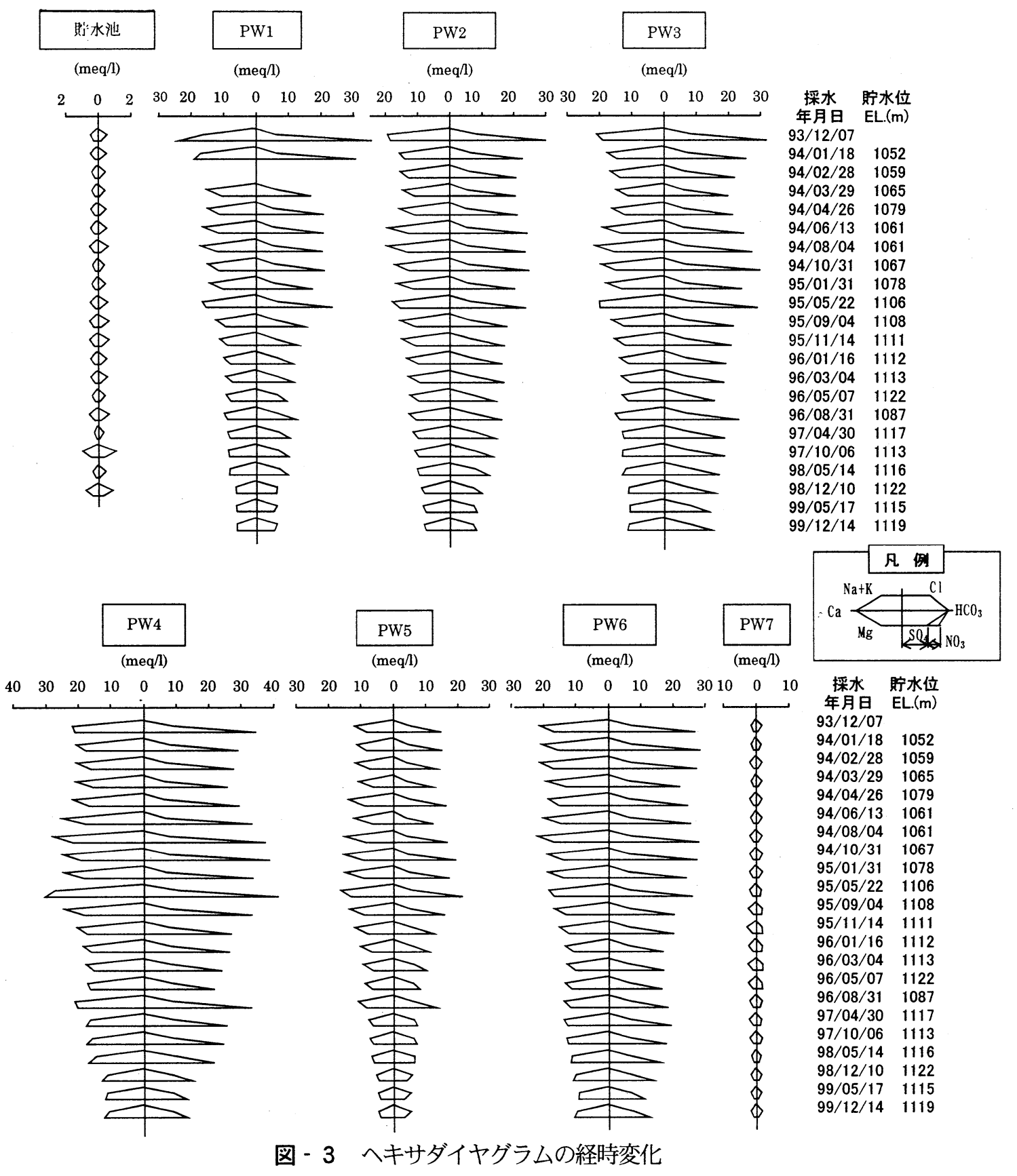

より深部の濃度（電気伝導度）の高い地下水が押し 山され，その後貯水池水により希积されたものと考 えられる。

(5)電気伝導度は, 水位が一定では減少し, 水位が下が ると上昇する傾向がある。これは貯水位変化に伴う 浸透水の流速の変化による影響と考えられる.

(6)貯水池表面の電気伝導度は50〜 $160 \mu \mathrm{S} / \mathrm{cm}$ で変化 を示し, 浸透水PW1からPW6よりも1オーダ低い.

\section{4. 電気伝導度のモデル化}

先に示した水質データから, 電気伝導度 $(E)$ が他の
溶存成分の濃度 $(C)$ も反映した代表的指標 $(E \propto C)$ として考えられるため電気伀導度を対象に, その経時変 化特性のモデル化を試みる.

PW1からPW5で計測される浸透水のコア部を浸透す る量は岩盤部の浸透量より十分少ないと考えられる.こ のため, この浸透水の流れを図 - 4 に示すような貯水池 から堤体下部岩盤を浸透し堤体下流に至る 1 次元の浸透 経路のモデルで表現することとした.

モデル化に際しては以下 4つの仮定をした.

(1)流速は貯水池水位と下流との動水勾配に比例し, 浸 透経路内での流速は一定

(2)貯水池からは電気伝導度の小さい一定値の電気伝導 度を有する貯水池水が流入

(3)流動経路内では元々の地下水と浸透水の電気伝導 


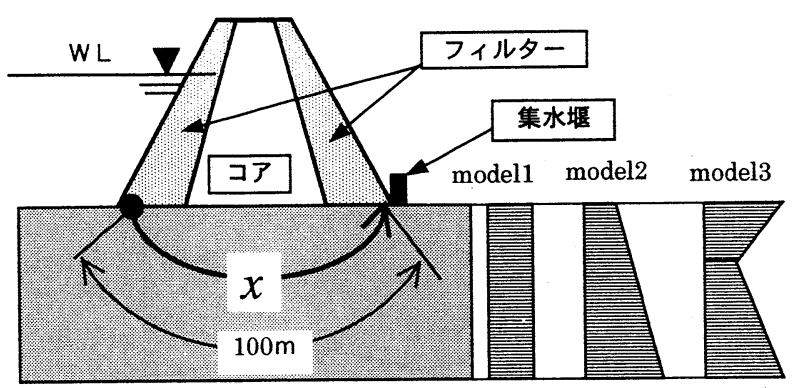

電気伝营度の

深度方向分布

図－4 貯水池から堤体下流に至る浸透経路の概念図と モデル化した初期の岩盤内電気伝導度の深度方向分布

度の差に応じた岩盤からのイオンの溶出による電 気伝導度の湧きだしが発生

(4)分散は無視

上記仮定に基づき, 電気伝導度 $E(\mu \mathrm{S} / \mathrm{cm})$ は次式 (1) で表現される.

$$
\frac{\partial E}{\partial t}=\frac{\partial}{\partial x}(u \cdot E)+q
$$

ここで, $t$ : 時間（day）， $x$ : 浸透経路に沿った距離

(m)， $u$ : 浸透流流速（ダルシー流速を有効間隙率 (0.05と仮定)で除したもの）（m/day）, $q$ : 系外からの 流入出項（岩盤からのイオンの溶出による電気伝導度の 増加を示す））（ $\mu \mathrm{S} / \mathrm{cm} / \mathrm{day} ）$

式(1)を差分形式で表現したものが次の式(2)(3)である. 式(2)は貯水池に接する要素, 式(3)は他の要素に対応す る. ここで岩盤からのイオンの溶出に伴う電気伝導度の 増加（涌き出し）は, ある参照電気伝導度 $E_{r e}$ と対象要 素内の電気伝導度との差に比例すると仮定している.

$$
\begin{aligned}
& E_{0}^{t+1}=E_{0}^{t}+u \cdot \Delta t \cdot\left(E_{\text {resev }}-E_{0}^{t}\right) / L+\alpha \cdot \varepsilon \cdot \Delta t \cdot L\left(E_{\text {ref }}-E_{0}^{t}\right) \\
& E_{i}^{t+1}=E_{i}^{t}+u \cdot \Delta t \cdot\left(E_{i}^{t}-E_{i-1}^{t}\right) / L+\alpha \cdot \varepsilon \cdot \Delta t \cdot L\left(E_{\text {ref }}-E_{i}^{t}\right)
\end{aligned}
$$

$L:$ 差分要素の長さ $(\mathrm{m}), \Delta t:$ 時間差分（day）, $E_{\text {resev }}$ : 貯水池水の電気伝導度 $(\mu \mathrm{S} / \mathrm{cm}), \alpha:=0$ $\left\{E_{r e f} \leqq E_{t}\right\},=1\left\{E_{r e f}>E_{t}\right\}, \varepsilon:$ 岩盤からのイオ ンの溶出による電気伝導度の湧き出し倸数 $(1 / \mathrm{m} /$ day $)$ を示す. 上付き添え字は時間, 下付き添え字は貯水池側 から下流に至る場所の位置（上流から数值は大きくな る)を示している.

初期条件のモデル（初期岩盤内における深度方向の電

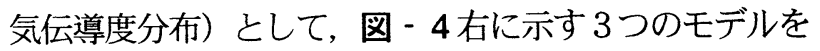
設定した. model1は深度方向の電気伝導度一定の場合, model 2 は深部に向かい電気伝導度が増加する場合, model3は表層部で電気伝導度が減少し，その下部では電 気伝導度が増加する場合である. 浸透経路に沿った初期 の濃度分布は図 - 5 のカーブマッチングの結果の下に各 modelごとに示している.

ここではPW2, PW3 ,PW4の電気伝導度の経時変化を

\begin{tabular}{|c|c|c|c|c|c|c|c|}
\hline & & 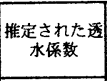 & 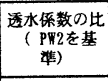 & 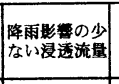 & 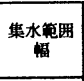 & 単位鹤光大 & 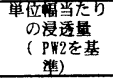 \\
\hline & 記号 & $\mathrm{k}$ & $\mathrm{k}_{\mathrm{pw}} / \mathrm{k}_{\mathrm{pw} 2}$ & Q & w & $q$ & $q_{p w i} / q_{p w 2}$ \\
\hline & 単位 & $\mathrm{m} / \mathrm{s}$ & - & $\mathrm{L} / \mathrm{min}$ & $\mathrm{m}$ & $\mathrm{L} / \mathrm{min} / \mathrm{m}$ & - \\
\hline \multirow{3}{*}{ PW2 } & model1 & $1.1 \mathrm{E}-07$ & 1.00 & \multirow{3}{*}{25.7} & \multirow{3}{*}{67} & \multirow{3}{*}{0.38} & \multirow{3}{*}{1.00} \\
\hline & model2 & $1.0 \mathrm{E}-07$ & 1.00 & & & & \\
\hline & model3 & $1.2 \mathrm{E}-07$ & 1.00 & & & & \\
\hline \multirow{3}{*}{ PW3 } & model1 & $1.2 \mathrm{E}-07$ & 1.11 & \multirow{3}{*}{77.8} & \multirow{3}{*}{93} & \multirow{3}{*}{0.84} & \multirow{3}{*}{2.18} \\
\hline & model 2 & $1.2 \mathrm{E}-07$ & 1.15 & & & & \\
\hline & model3 & 7.3E- 08 & 0.63 & & & & \\
\hline \multirow{3}{*}{ PW4 } & model1 & $5.0 \mathrm{E}-08$ & 0.46 & \multirow{3}{*}{43.7} & \multirow{3}{*}{66} & \multirow{3}{*}{0.66} & \multirow{3}{*}{1.73} \\
\hline & model 2 & $8.2 \mathrm{E}-08$ & 0.79 & & & & \\
\hline & model3 & $8.3 \mathrm{E}-08$ & 0.71 & & & & \\
\hline
\end{tabular}
対象に実測值とモデルによるカーブマッチングを実施し,
表 - 2 推定された透水係数と計測された浸透量

浸透経路の上下流方向の平均透水係数, 初期の電気伝導 度分布, 岩盤からのイオンの溶出による湧き出し倸数を 推定した. カーブマッチングでは, (1)解析值と実測值の 差の二乗和を最小, (2)1994末〜1995中頃に電気伝導度の ピークとなるとする, (1)(2)二つの視点から最適なパラ メータを推定した. パラメータを変化させ, 本手法によ る最適パラメータの一意性を確認した. 䛊差の二乗和の 計算は式 (2) (3)を市販の表計算ソフトMSエクセルへ適 用し, 最適なパラメータをソルバー機能により推定した. 推定結果を表 - 2, 図-5に示す.

表 - 2 は推定された透水係数と実測浸透量をPW2, PW3，PW4の間で相対比較したものである. 浸透流量は 降雨の影響の少ない時点 $(1999 / 2 / 10)$ での值を示して いる. 比較を容易にするためPW2を基準に透水係数, 単位幅当たりの浸透量を正規化した值を併記した. 推定 された透水係数と浸透量の大小関係は一致していないが, 各集水区間ごとで初期条件（model1～model3）に係わら す類似した透水係数を示していることがわかる. また基 礎処理の改良目標值はカーテン部 $\mathrm{k}=4 \times 10^{-7} \mathrm{~m} / \mathrm{s}$ (3Lu), ブランケット部 $\mathrm{k}=1 \times 10^{-6} \mathrm{~m} / \mathrm{s}$ (10Lu) であり, 推定された 透水係数とほぼ同じオーダーで, 推定結果がほぼ妥当な 結果であると考えられる. 推定された透水係数は目標値 を下回り, グラウチングの施工は目標を達成したと考え ることができる.

図－5ではカーブマッチングの結果の下に各modelに よる上下流方向の初期, 1 年後, 6 年後の電気伝導度分 布を示している. 図 - 5に示すカーブマッチングの結果 は, 初期条件modelにより多少の違いは認められるが, 計測された電気伝導度の変化傾向をよく再現している. 特にmodel3では湛水初期の電気伝導度の減少傾向も含め よく再現されている.

\section{5. まとめ}

本研究では大規模ダムの初期湛水から 6 年あまりの堤 体基礎岩盤浸透水の水質調查を継続し，浸透水の水質変 化を示した. また, 電気伝導度デー夕を対象に移流と岩 盤からの溶出効果を考慮したモデル化を適用し, 電気伝 

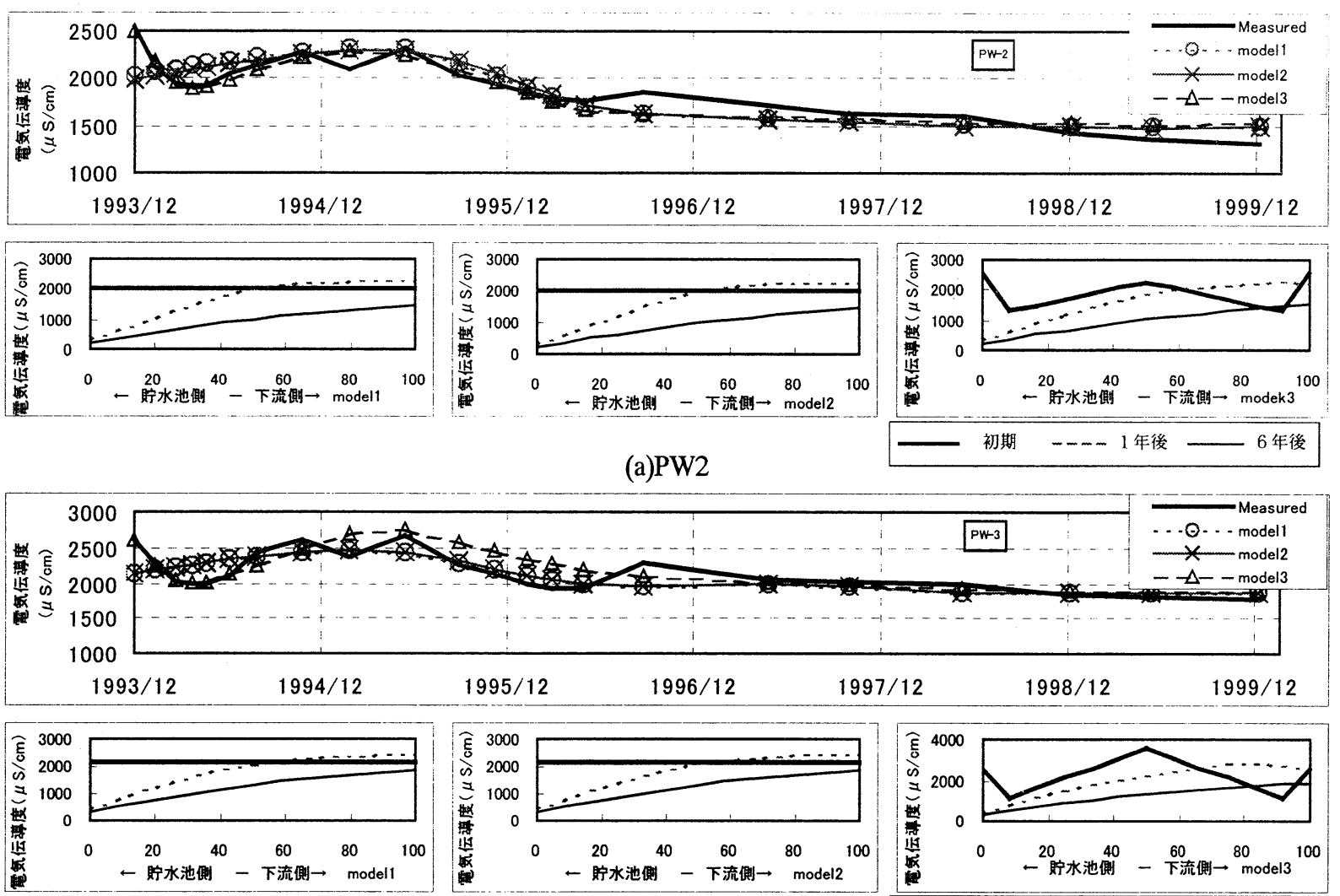

(b)PW3
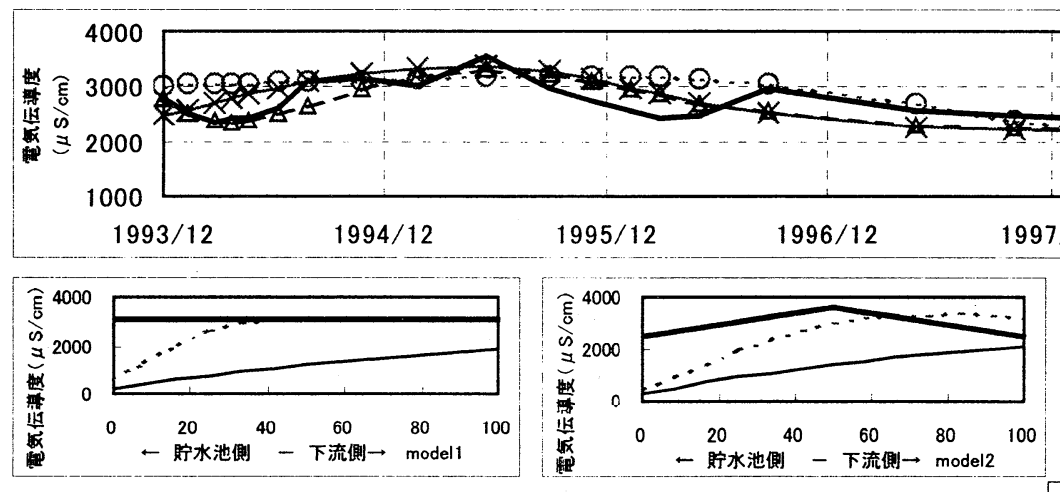

(c) PW4

$\longrightarrow$ 初期 ----1 年後 $\longrightarrow 6$ 年後

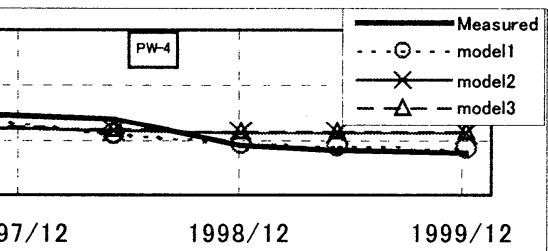

図 - 5 モデルによる各集水区間の電気伝導度の経時変化

(初期条件の 3 種類のmodelによる経時変化の違い $<$ 上 $>$ と

上下流方向の電気伝導度分布＜下の 3 グラフ, 左からmodel1, mode12, model3の順>を示す．）

導度デー夕から定量的に基礎岩盤の透水係数を推定 して堤体の安定性を評価する手法を提案し，その適 用結果を示した。このモデルは計測された水質の変 化をよく再現し，推定された透水係数もほぼ妥当な ものと考えられた。

今後は貯水池から下流へ向かう浸透経路途中での 水質を調查し，電気伝導度の空間的分布の観点から ここで示された結果と比較し，ここで示したモデル の検証を実施する予定である.

\section{参考文献}

1) 小野寺直ほか: 味噌川ダム初期湛水時の浸透流 挙動，水工学論文集，第41巻，pp. 549-556， 1997

2 ) 塩崎功汸：水質・水温を利用した上大須ダム 初期湛水時地下水流動調查, 土木学会論文集 No. 576 / II -41， pp. 177-189, 1997

3 ）小野寺直ほか：味噌川ダム初期湛水時における 堤体の安定性，水の技術，No. 3, pp. 71-81, 1998

4) 塩崎功ほか：水質・同位体を利用した川浦夕゙ 厶・川浦鞍部夕゙么初期湛水時地下水流動調查, 土 木学会論文集No. 576／II -41，pp. 163-176, 1997

(2000. 10. 2受付) 